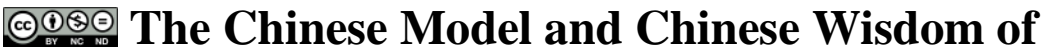 Modernization ${ }^{1}$
}

\section{Li Xiaodong*}

\begin{abstract}
The Soviet model of socialism and the American model of capitalism are the two major solutions to modernization. Under the guidance of the traditional Chinese Doctrine of the Mean and the Marxist dialectical materialism, the Communist Party of China, by successively learning from these two major solutions and combining with the actual situation of China, has proposed Chinese solutions of socialism with Chinese characteristics to modernization of state governance and thus offered to the world Chinese wisdom beyond the conflicts between two major ideologies, namely, socialism and capitalism.
\end{abstract}

Keywords: State governance. Modernization. Chinese wisdom. Chinese situations.

\footnotetext{
${ }^{1}$ This paper is related to "the Research of the Relationship between the Thought of the Communist Party of China about state Governance and Excellent Traditional Chinese Culture" supported by Beijing Social Science Fund Research Project Base (Project No. 17JDKDB003).
}

* Associate Professor and Assistant Dean of the School of Marxism of Beijing Jiaotong University, Researcher from CITIC Institute for Reform and Development Studies, Juris Doctor. E-mail: xdli@bjtu.edu.cn, ORCID:https://orcid.org/0000-0001-6214-2635 01051685053,13681582664. Contact address: Li Xiaodong, the School of Marxism of Beijing Jiaotong University, No. 3 Shangyuan Village, Haidian District, Beijing, 100044. 


\section{O modelo chinês e a sabedoria chinesa da modernização}

Resumo: O modelo soviético de socialismo e o modelo americano de capitalismo são as duas principais soluções para a modernização. Sob a orientação da doutrina chinesa tradicional do caminho do meio e do materialismo dialético marxista, o Partido Comunista da China, aprendendo sucessivamente com essas duas soluções principais e combinando-se com a situação atual da China, propôs soluções chinesas de socialismo com características chinesas, modernização da governança do estado e, assim, ofereceu ao mundo a sabedoria chinesa além dos conflitos entre duas grandes ideologias, a saber, socialismo e capitalismo.

Palavras-chave: Governança estatal. Modernização. Sabedoria chinesa. Situações chinesas.

\section{El modelo chino y la sabiduría china de la modernización}

Resumen: El modelo soviético del socialismo y el modelo estadounidense del capitalismo son las dos soluciones principales para la modernización. Bajo la guía de la Doctrina tradicional china de la media y el materialismo dialéctico marxista, el Partido Comunista de China, al aprender sucesivamente de estas dos soluciones principales y combinar con la situación actual de China, ha propuesto soluciones chinas del socialismo con características chinas para modernización de la gobernanza estatal y, por lo tanto, ofreció al mundo sabiduría china más allá de los conflictos entre dos ideologías principales, a saber, el socialismo y el capitalismo.

Palabras clave: Gobernanza estatal. Modernización. Sabiduría china. Situaciones chinas. 
The modern history of China shows that properly dealing with the relationship between traditional culture and modernization is a major theoretical issue that determines the destiny of contemporary China. Too much emphasis on traditional Chinese culture may lead to deterioration of reform and revolution. For example, Empress Dowager Cixi put forward that "the law made by forefathers shall not be changed", Kang Youwei proposed to set Confucianism as the state religion, Yuan Shikai worshipped Confucius as a God, and Chiang Kai-Shek brought forward the so-called New Life Movement. All those were excuses for advocating feudal autocracy. However, too much emphasis on modernization may be divorced from the actual situation of China, thus leading to failure of Chinese revolution and reform. For example, the main reason for the failure of Hong Xiuquan to worship the God and establish Taiping Heavenly Kingdom, the failure of Kang Youwei and Liang Qichao to advocate constitutionalism and the failure of Sun Yat-sen to promote the republic revolution is that western religious doctrines and the democracy and freedom regime are inconsistent with Chinese traditions, which is typically characterized by the failure of Soviet students represented by Wang Ming within the Communist Party of China.

\section{First, Argument on Traditional Chinese Wisdom and Modernization of the Country}

Due to noting the inevitable huge impact of traditional Chinese culture on contemporary China, many foreign scholars have long been 
interested in studying China from the perspective of the intellectual history, among whom the most influential ones were John King Fairbank from Harvard University and his brilliant students Joseph Richmond Levenson and Benjamin Isadore Schwartz whose views were also three kinds of the most representative views.

Fairbank, in his works such as China: Tradition and Transformation, New Views of China's Tradition and Modernization and The Great Chinese Revolution, investigated China from the cultural perspective that China is a civilized country rather than a national state in history and he found the amazing stability and continuity of Chinese history and culture. He said that Mao Zedong Thought "is in harmony with some remnants of Confucianism such as the reverence for authority and the sense of obligation based on identity". Nevertheless, "Marxism with Chinese features also conforms to the superiority of scientific explanation but refuses to accept the principle of 'Yin-Yang', 'Li-Qi' and the like."' However, "Deng Xiaoping's patience in reform and practical style of work reminds people of Chinese tradition in ancient times of governing a country when scholars and officials cared much about people's livelihood and alleviated people's concerns. Relatively, our goal currently is still to build a stronger and more humane society. "2 In brief, as Fairbank thought, "Western countries impact on Chinese intellectual circle for twice: Liberalism and Marxism, both of which are the highest development stage of our western cultural imperialism. Like a saddle, it's not really

\footnotetext{
${ }^{1}$ John King Fairbank, The Great Chinese Revolution, World Affairs Press, 2001, 433.

${ }^{2}$ John King Fairbank, China: Tradition and Transformation, World Affairs Press, 2002, 654.
} 
appropriate for China." "It's the best choice for China to reform with its own pattern." That is to say, traditional Chinese ideology and culture haven't been completely weak under the influence of western Liberalism and Marxism.

Joseph Richmond Levenson proposed a completely different view from his teacher in his book Confucian China and Its Modern Fate that although Confucians and Marxists paid equal attention to the study of history, "Marxists' view of history naturally centers on linear development of each historical period, while Confucians' view of history generally attaches less importance on the process of historical evolution but more on the explanation of the eternal and constant moral idea put forward by Confucians. ...The communist progressive view of history is not only a break with traditional Confucianism, but also a way to explain such break." In other words, Levenson deemed that Chinese communists' or Chinese Marxists' view of history is revolutionary and progressive which not only completely opposes Confucians' conservative view of history that pursues the eternal order, but also denies Confucianism and Chinese historical tradition in the name of revolutionary progress. In Chinese communists' view of history, traditional cultures such as Confucianism, Taoism and Buddhism are feudalism, which couldn't guide socialist revolution led by the Communist Party of China and the direction of Chinese history after all. Levenson believed that communists consider that

\footnotetext{
${ }^{3}$ John King Fairbank, The Great Chinese Revolution, World Affairs Press, 2001, 433.

${ }^{4}$ John King Fairbank, The Great Chinese Revolution, World Affairs Press, 2001, 434.

${ }^{5}$ Levenson, Confucian China and Its Modern Fate, China Social Sciences Press, 2000, 310311.
} 
Confucianism is "feudal" and is a "hierarchical but not national tradition". Therefore, "the communists who commemorate Confucius's birthday are merely singing a coronach for him to send him to the tomb of history"7. Accordingly, in Levenson's opinion, no any continuity or uniqueness of Chinese history exist as Fairbank said, and "the river of Chinese history is drying up or simply being incorporated into the tide of the West ${ }^{8}$. Thus, by accepting no matter whether libertarians or Marxists, Chinese history will eventually converge to the river of Western capitalist and socialist history. This is a typical view of historical nihilism.

The researches carried out by Fairbank and Levenson were both from the past to the present of China, while the difference is that the former focused on drawing a conclusion from historical vicissitude but the latter focused on the change of thinking method. Nevertheless, Schwartz conducted researches by tracing the history and culture of China from the modern times, so he gave emphasis to the need of realistic strategies for theoretical reform. Schwartz believed that due to the reality of Chinese revolution, Marxism experienced a slow but continuous process of disintegration in its eastward development - into an environment beyond the original expectation". Although "each step of the process is restrained and offset by a strong 'orthodox will' (closely related to the power and interests of groups involved)", "whenever the circumstances ultimately lead to an unanticipated course of action, every effort will be made to

\footnotetext{
${ }^{6}$ Levenson, Confucian China and Its Modern Fate, China Social Sciences Press, 2000, 316.

${ }^{7}$ Levenson, Confucian China and Its Modern Fate, China Social Sciences Press, 2000, 324.

${ }^{8}$ Levenson, Confucian China and Its Modern Fate, China Social Sciences Press, 2000, 311.

${ }^{9}$ Schwartz, Chinese Communism and the Rise of Mao, published by Renmin University of China, 2013, Introduction 66-67. https://doi.org/10.4159/harvard.9780674432956
} 
prove that such action is in fact preconceived, and then new rational explanations will be conceived to make new experiences confirm to the carefully constructed consistent correct and superior appearance ${ }^{10}$." Thus, although the trend is towards division, we still believe other core principles of Marxism-Leninism are the complete and vivid principles of Chinese communism ${ }^{11}$ ". However, "when reviewing the strange event of 'Cultural Revolution' and thinking about how the peaceful image of Chairman Mao can be the source of all morality and tower above all laws and institutions, people may attribute their views to Chinese culture rather than any western thought ${ }^{12}$." In other words, Chinese socialism generally conforms to the principles of Marxism, but merely because of the influence of Chinese culture the localization of Marxism in China makes it less like western thoughts.

Due to different emphasis to the history, reality and theory, western scholars have drawn three conclusions on the study of traditional Chinese culture and socialism. Although traditional Chinese culture hasn't changed fundamentally because of Chinese revolutions and been completely negated by Marxism or Liberalism, it has deeply influenced Marxism and made Marxism localization. In addition, overseas Chinese scholars such as Yu Ying-shih, Tu Weiming, et al., have also written some books about Chinese history and culture and the thoughts and theory of the Communist Party of China. For example, Tu Weiming' paper: Cultural

\footnotetext{
${ }^{10}$ Schwartz, Chinese Communism and the Rise of Mao, published by Renmin University of China, 2013, Introduction, 67. https://doi.org/10.4159/harvard.9780674432956

${ }^{11}$ Schwartz, Chinese Communism and the Rise of Mao, published by Renmin University of China, 2013, 163. https://doi.org/10.4159/harvard.9780674432956

${ }^{12}$ Schwartz, Chinese Communism and the Rise of Mao, Renmin University of China, 2013, 182. https://doi.org/10.4159/harvard.9780674432956
} 
China - The Periphery as the Center represents overseas Confucians' basic viewpoint, namely, communism undermined and abandoned Confucianism, and Confucianism were better preserved and inherited in Japan, South Korea, Europe and America and other overseas countries ${ }^{13}$. Negatively impacted by the "Cultural Revolution", scholars from Hong Kong and Taiwan generally believe that the Communist Party of China destroyed traditional Chinese culture. Therefore, many overseas Chinese believe that excellent traditional Chinese culture can only be found out overseas because it has been uprooted by the Chinese mainland.

The point of view that the Communist Party of China destroyed traditional Chinese culture has long been a common view in Chinese mainland academic circles and may have been claimed as a victory of the Communist Party in cultural reform at some point. However, as some studies have been deepened in recent years, the viewpoint that revolution destroyed traditional culture has been questioned. Liu Xiaofeng put forward in books titled A study of the Headstream of Confucian Revolutionary Spirit and Confucianism and National State that although the basic content of Mao Zedong's revolutionary ideas come from Marxism, the spiritual origin is Confucian revolutionary thoughts such as Tang Wu's revolutionary theory of justice, the legitimacy of the Chinese state system, the "Crownless King's" revolution and sacred heart. Therefore, Chinese revolutions reflect the concept of "setting things right" and "governing the country and the world", and Chinese socialism is inevitably related to Confucian thoughts such as "being well-off" and

${ }^{13}$ Tu Wei-ming, Cultural China: the periphery as the center. Daelalus, Spring, 1990, 120122. 
"Great Harmony" 14 . In The Integration of Three Traditions, Gan Yang proposed that the traditions of Confucius, Mao Zedong and Deng Xiaoping are extension of China's historical civilization ${ }^{15}$, and China's modernization and rejuvenation of Chinese culture must experience the integration of these three traditions towards the development direction of "Confucian socialism." Gan Yang has also compiled Confucius and Contemporary China ${ }^{16}$ with Chen Lai, including viewpoints of some philosophical, economic and legal scholars on traditional Chinese culture and modern China, including Tang Yijie, Tu Weiming, Yeo-Chi King, Daniel A. Bell, He Huaihong, Zhang Rulun, Zhang Xianglong, Jiang Qing, Sheng Hong and $\mathrm{Su} \mathrm{Li}$. Their basic viewpoints were generally that Confucianism has always maintained its influence on China's reality and that China should also seek roots from traditional Chinese culture in the process of realizing modernization. Among these scholars, Daniel A. Bell, a Canadian scholar who taught at Tsinghua University is particular worthy of special mention. He has published several works in English such as Chinese Ancient Thought, Modern Chinese Power, China's New Confucianism, Confucian Political Ethics, Confucianism for the Modern World, Beyond Liberal Democracy, Communitarianism and Its Critics, which not only discussed the relationship between Confucianism and contemporary Chinese ideological and political theory, but also proposed

\footnotetext{
${ }^{14}$ Liu Xiaofeng, A study of the Headstream of Confucian Revolutionary Spirit, SDX Joint Publishing (Life, Reading and New Knowledge), 2000.

${ }^{15}$ Gan Yang, The Integration of Three Traditions, SDX Joint Publishing (Life, Reading and New Knowledge), 2007, 6.

${ }^{16}$ Chen Lai and Gan Yang, Confucius and Contemporary China, SDX Joint Publishing (Life, Reading and New Knowledge), 2008.
} 
that traditional Confucianism contains Chinese wisdom beyond the modern western liberal democracy.

The debate about traditional Chinese culture and contemporary China is not just a historical debate in fact, but a debate about China's development trend in the future. The commentators, who hold the view that the continuity of Chinese history and the vitality of traditional Chinese culture are extremely strong, basically believe that China will continue to follow its own path instead of merging with the West. Nevertheless, the commentators who believe that Chinese revolution abandoned traditional Chinese culture argue that Chinese revolution has fundamentally changed the course of Chinese history and both Marxism and Liberalism will bring Chinese history into the flow of western history.

\section{Second, Chinese Revolution and Reform with Unique Chinese Cultural Characteristics}

Ancient China proceeding to modern times really makes people feel no way out. The failure of Taiping Rebellion, the Westernization Movement and the Hundred Days' Reform shows that the road to maintaining absolute monarchy is completely blocked. It's generally acknowledged, by western scholars and political circles in particular, that Chinese revolution was intending to overthrow the monarchy and the revolution whether led by Kuomintang or the Communist Party of China was in fact imitating the attempt of the west. The only difference was following an American or Soviet pattern. The Revolution of 1911 led by 
Kuomintang tried to follow the American pattern, while the New Democratic Revolution and the socialist revolution led by the Communist Party of China tried to follow the Soviet pattern. However, the point is that this was only one aspect of the problem and Chinese people also wanted to overthrow imperialism in addition to feudalism. The purpose for which Sun Yat-sen led bourgeois-democratic revolution was not following the American pattern in fact. "The Three Principles of the People", especially "New Three Principles of the People" proposed by Sun Yat-sen after Kuomintang-Communist cooperation, was distinct from American's laissez-faire capitalism. The Nationalism advocated by Sun Yat-sen was "nothing but anti-imperialism", Democracy meant "the state power was jointly enjoyed by common people rather than by the minorities", and the People's Livelihood "centered on nothing but two most important principles, i.e. equalization of land ownership and regulation of capital".

The distinction between the New Democratic Revolution led by the Communist Party of China and the Great October Socialist Revolution is even more pronounced. The New Democratic Revolution is a bourgeoisdemocratic revolution with new features and contents, which is different from the old bourgeois-democratic revolution and proletarian revolution. From the perspective of opposing colonial aggression and feudal oppression, it's a bourgeois-democratic revolution similar to the Independence War led by Washington. Nevertheless, the New Democratic Revolution was led by the proletariat and its vanguard, i.e. the Communist Party of China, so from this point of view, it is similar to the Great October Socialist Revolution. Therefore, the Communist Party of China in the Yan'an Period was supported by the Soviet Union and, to a certain extent, 
recognized by Americans such as Edgar Snow and Agnes Smedley. However, Americans were wary of the Communist Party and communism and the Soviet Union also questioned the reliance of Chinese revolution on farmers. Americans wished Chinese not to follow the path of socialist revolution and soviets hoped that Chinese revolution would rely more on the working class. In fact, the bourgeois-democratic revolution led by Kuomintang and supported by the Communist Party ultimately failed, nor did the proletarian revolution which relied on the working class to launch the uprising against central cities. Neither catering to the old bourgeoisdemocratic revolution nor imitating the new proletarian revolution could bring the Chinese revolution a success. Chinese revolution must on the one hand rely on the strong leadership of the proletariat and the guidance of Marxism, but on the other hand depend on the peasant class and the urban petty bourgeoisie and cooperate with national bourgeoisie to establish the broadest revolutionary united front. That is the New Democratic Revolution theory.

The theory of New Democratic Revolution was deemed very strange by people at the outset, because it was neither Soviet proletariansocialist revolution nor American bourgeois-democratic revolution. The New China founded after the success of New Democratic Revolution was neither a socialist country like Soviet Union and Eastern Europe nor a capitalist country like America, but was a new democratic country. Neither a state of dictatorship of the proletariat nor a state of democracy of the bourgeoisie, a new democratic country is of joint dictatorship of revolutionary classes led by the working class and based on the alliance of workers and farmers, independent of "one-party system" but subject to 
multiparty cooperative system. However, it never supported multiparty election but supported multiparty cooperation led by the Communist Party of China. Economically, the new China didn't exterminate the capitalist economy as the Soviet Union and Eastern Europe did. On the contrary, the New China allowed the existence and development of national industry and commerce and it was of course unlike a capitalist country which is dominated by private ownership but was dominated by state operated economy. With respect to ideology and culture, Marxism was undisputedly its guiding ideology and the guidance against Marxism was not allowed in the New China. Nevertheless, the New China hadn't mentioned the idea of "unification", but on the contrary it advocated different styles and flows of ideas. Despite of fundamental changes in economic, political and cultural systems in specific implementation, especially after the socialist transformation, the flexibility of policy had never been abandoned.

\begin{tabular}{|c|c|c|c|}
\hline Categories & $\begin{array}{c}\text { Great October } \\
\text { Socialist Revolution } \\
\text { (Lenin) }\end{array}$ & $\begin{array}{c}\text { New Democratic } \\
\text { Revolution } \\
\text { (Mao Zedong) }\end{array}$ & $\begin{array}{c}\text { The } \\
\text { Independence } \\
\text { War }\end{array}$ \\
\hline Target & $\begin{array}{c}\text { Tsarist autocracy } \\
\text { and bourgeoisie }\end{array}$ & $\begin{array}{c}\text { Foreign imperialism, } \\
\text { local feudalism and } \\
\text { bureaucrat-capitalism }\end{array}$ & $\begin{array}{c}\text { British } \\
\text { imperialism }\end{array}$ \\
\hline Force & Workers & Farmers & $\begin{array}{c}\text { Capitalists/slave } \\
\text { owners }\end{array}$ \\
\hline Objective & Socialist country & New democratic country & $\begin{array}{c}\text { Democratic and } \\
\text { liberal country }\end{array}$ \\
& & & \\
\hline
\end{tabular}




\begin{tabular}{|c|c|c|c|}
\hline Nature & $\begin{array}{c}\text { Proletarian- } \\
\text { Socialist revolution }\end{array}$ & $\begin{array}{c}\text { Proletarian-democratic } \\
\text { revolution }\end{array}$ & $\begin{array}{c}\text { Bourgeois } \\
\text { democratic } \\
\text { revolution }\end{array}$ \\
\hline
\end{tabular}

The key to the success of Chinese revolution is that China neither blindly imitated the Soviet Union for socialist revolutions nor imitated the United States for bourgeois-democratic revolution. Besides, China never blindly copied the practices of Soviet and Eastern Europe for socialist transformation, so Chinese socialist transformation went more smoothly than that of Soviet and Eastern Europe. Although China failed to surpass the Soviet pattern of socialism before the reform and opening-up policy, the ideology of exploring socialism with Chinese characteristics has been deeply rooted in China.

The success of Chinese revolution made Chinese people more influential from then on, which meant not only that China would no longer been subject to foreign aggression, plunder and exploitation, but also that Chinese people became stronger mentally and spiritually. China would no longer copy western countries' success, but would dare to learn from western countries successful experiences while taking a road suited to its own national conditions; would no longer worship western thoughts and theories, but would dare to summarize its own practical experience and form its own ideological theories while absorbing western ideological theories. The theory of socialism with Chinese characteristics is gradually formed by summarizing experiences of China's socialist revolution and 
construction and drawing on the experience of Soviet Union, other Eastern Europe socialist countries and western capitalist countries.

The socialism with Chinese characteristics not only differs from the Soviet Union pattern of socialism, but also varies from the laissez-faire American model of capitalism. The socialism with Chinese characteristics integrates and surpasses the Soviet Union pattern of socialism and American model of capitalism, creatively proposing the new socialist road, theory and system. Although the theory system of socialism with Chinese characteristics is still in the process of continuous perfection and development, it has already preliminarily formed the basic institutional features. The socialist market economic system is the organic combination of the basic Socialist economic system and market economy, and the economic demonstration of the socialism with Chinese characteristics. Therefore, it not only has the institutional features of socialism, but also has the general features of market economy. It adheres to taking the public ownership \& distribution according to one's performance as main body and the objective of common prosperity, which not only makes the market play the decisive role in the resource allocation, but also emphasizes the macrocontrol of government. Politically, the socialism with Chinese characteristics does not accept the Western democracy, but draws the historical lessons of proletarian dictatorship from the Soviet Union \& Eastern European countries, stressing the combination of democracy for the people and dictatorship over the reactionaries. China will neither implement the western two-party or multi-party system, nor implement the single-party system of Soviet Union \& Eastern European countries. Instead, China will continuously develop and perfect the system of multi- 
party cooperation under the leadership of the CPC. China does not carry out the western separation of powers, but adheres to objecting and preventing from the feudal-patriarchal system, and also adheres to and perfects the system of people's congress. China neither conducts the federalism, nor conducts the Unitary system. Instead, on the basis of Safeguarding the national unity and the authority of the CPC Central Committee, China sticks to and perfects the "One Country, Two Systems" and "System of Regional Ethnic Autonomy". Ideologically and culturally, China neither denies the Marxism, nor dogmatically treats the Marxism. Instead, China not only carries forward the theme, but also advocates the diversity. Besides, China also adheres to continuously pushing forward the Marxist theoretical innovation as per the reality of contemporary China and the underlying features of our times, adheres to combining the cultural undertakings with the economic and social benefits, and puts the social benefits in the first place.

The Soviet Union pattern of socialism, and the American model of capitalism are two major ideological systems that guide the development direction of all countries in the world. Actually, China does not go either way. In the contrary, China has taken its own path, namely, the "doctrine of the mean" integrating these two major theoretical systems. The doctrine of the mean is the essence of Chinese culture, and the spirit of "The sea encompasses hundreds of rivers, willingness to accept all is virtuous" gradually developed during the process of the contention of a Hundred Schools of Thought and the wars of the spring \& autumn and warring states. In his book Confucian China and its Modern Fate, the late scholar Levenson from the Harvard University in USA pointed out that the 
ideological characteristics of Confucianism is "the doctrine of the mean" and its social characteristics are the balanced action played between the feudal aristocracy and absolute monarch. All Taoist ways lead to egoism, while the ego is the most concern of Taoism, or "no ego" expressed in the Taoist language, namely, liberating and saving yourself from the selfconsciousness of inevitable death. Legalism is the "without" social extremism opposite to the "within" Taoism, emphasizing the state governance and social order, and believing that the social order may be achieved through laws and violence. Different from the Taoist one-sided emphasis on ego and Legalist one-sided emphasis on state, the Confucianism advocates the active worldly ideology of "self cultivation, family harmony, country management and world peace" ${ }^{17}$. However, such variation of the Confucianism is not the denial of Taoism and Legalism. On one hand, in fact, the Confucianism also pursues the Taoist "governing by non-interference" ideal, namely, reaching the "Great Harmony" status of social or civil self-governance. Therefore, China under the guidance of Confucianism has always been the "small government and large society". On the other hand, the Confucianism also agrees the Legalist state governance and social order establishment ideas, and the Confucian officials always rely on the laws and violence to govern the state. However, compared with the Taoism, the Confucianism plays a more positive and optimistic role upon the government. Actually, the Confucianism believes "The root of the world is at the state, and the root of the state is at the household, while the root of the household is at the

${ }^{17}$ Levenson, Confucian China and its Modern Fate, China social sciences press, 2000, 360361. 
individual". ${ }^{18}$ Therefore, in order to realize the Taoist "governing by noninterference" ideal of social self-governance and world peace, it is necessary to properly govern the state at first, and further bring the wellbeing to the people and maintain the long social stability on this basis. Meanwhile, Confucianism objects the Legalist pattern of state governance by severe laws. In contrary, Confucianism believes that "If you govern the people legalistically and control them by punishment, they will avoid crime, but have no personal sense of shame. If you govern them by means of virtue and control them with propriety, they will gain their own sense of shame, and thus correct themselves" ${ }^{\prime 19}$. Therefore, the essence of proper state governance is self-cultivation.

\begin{tabular}{|c|c|c|}
\hline $\begin{array}{c}\text { Soviet Union } \\
\text { pattern of } \\
\text { socialism }\end{array}$ & Socialism with Chinese characteristics & $\begin{array}{c}\text { American model } \\
\text { of capitalism }\end{array}$ \\
\hline Public ownership & $\begin{array}{c}\text { Public ownership serving as its main } \\
\text { body but allowing for the joint } \\
\text { development of all types of ownership }\end{array}$ & Private ownership \\
\hline Plan & $\begin{array}{c}\text { Let the market play the decisive role in } \\
\text { allocating resources and let the } \\
\text { government play its functions better }\end{array}$ & Market \\
\hline
\end{tabular}

\footnotetext{
${ }^{18}$ Levenson, Confucian China and its Modern Fate, China social sciences press, 2000, 360361.

${ }^{19}$ Levenson, Confucian China and its Modern Fate, China social sciences press, 2000, 360 361.
} 


\begin{tabular}{|c|c|c|}
\hline $\begin{array}{l}\text { Distribution } \\
\text { according to } \\
\text { one's } \\
\text { performance }\end{array}$ & $\begin{array}{l}\text { Distribution according to one's } \\
\text { performance is dominant and a variety } \\
\text { of modes of distribution coexist }\end{array}$ & $\begin{array}{l}\text { Distribution by } \\
\text { contribution }\end{array}$ \\
\hline $\begin{array}{l}\text { Meet the people's } \\
\text { needs }\end{array}$ & People-oriented shared development & $\begin{array}{c}\text { Profit } \\
\text { maximization }\end{array}$ \\
\hline $\begin{array}{l}\text { Centralism/ } \\
\text { dictatorship }\end{array}$ & $\begin{array}{l}\text { Democratic centralism/ people's } \\
\text { democratic dictatorship }\end{array}$ & Democracy \\
\hline Discipline & Both discipline and freedom & Freedom \\
\hline $\begin{array}{l}\text { Unified/ } \\
\text { collective }\end{array}$ & $\begin{array}{c}\text { Both unity of will and personal ease of } \\
\text { mind }\end{array}$ & Personal \\
\hline $\begin{array}{l}\text { Single-party } \\
\text { system }\end{array}$ & $\begin{array}{c}\text { The system of multi-party cooperation } \\
\text { and political consultation under the } \\
\text { leadership of the CPC }\end{array}$ & $\begin{array}{l}\text { Multi-party } \\
\text { system }\end{array}$ \\
\hline $\begin{array}{l}\text { Guided by the } \\
\text { Marxism }\end{array}$ & $\begin{array}{c}\text { Carry forward the theme, and advocate } \\
\text { the diversity }\end{array}$ & Multi-culture \\
\hline "Left" & "Middle" & Right \\
\hline
\end{tabular}

Taoism and Legalism are two extremes, one of which pursues the laissez faire and the other of which pursues the political order. Instead, the Confucianism tries to pursue a balance between them, reaching the ideal 
state of mean and harmony. Such thinking mode and social ideal of mean and harmony enables the Confucianism to better absorb the essence of Taoism, Legalism and other Hundred Schools of Thought. For instance, the Confucian scholars have the Taoist temperament at the literature and art level, but still establish the system of etiquette and laws on the state governance level, which is the same as the Legalism. To the contrary, the Qin dynasty established by First Qin Emperor, and guided by the Legalism, Li Yu, "Last Ruler" of Southern Tang, who is indulged in Taoist literary and artistic aesthetics, and some worse emperors who are indulged in the alchemy, are dynasties and emperors deviating from the Confucian doctrine of the mean. As the Confucianism has the strong inclusion, Buddhism, Catholicism and Christianism are introduced to China afterwards, but they cannot be converted into the state religion. Instead, they can only affect the personal spiritual life, which is the same as Taoism. In the speech addressed by China's President Xi Jinping at UNESCO Headquarters in 2014, President Xi Jinping once pointed out that Buddhism appeared in ancient India, but was finally developed into the Buddhist culture with Chinese characteristics through the long-term evolution and the integration and development with China's Confucian culture and Taoist culture after being introduced to China; besides, it also deeply impressed Chinese people's religious belief, philosophic ideas, literature and art, etiquette and custom, and etc. As per the Chinese cultures, our Chinese people have developed the Buddhism, formed the unique Buddhist theory, and also spread the Buddhism from China to Japan, South Korea, Southeast Asia and other regions. At present, China's traditions developed through these historic experiences provide the unique 
wisdom to our Chinese people for handling the mutually contradictory ideological confrontation of socialism and capitalism. The impacts of western Marxism, liberalism, socialism and capitalism upon China is the same as Buddhist impacts upon China in history. It integrates and develops with China's traditional Confucianism, Buddhism, Taoism, Legalism and other cultures, forms the socialism with Chinese characteristics that is compatible with the socialism and capitalism, and is likely to further affect Viet Nam, Laos, North Korea, South Korea, Japan and other neighboring countries.

China's Traditional State Governance Wisdom \& Schemes and its Modern Analogy

\begin{tabular}{|c|c|c|}
\hline Legalism & Confucianism & Taoism \\
\hline $\begin{array}{c}\text { (Soviet Union pattern of } \\
\text { socialism) }\end{array}$ & $\begin{array}{c}\text { (Socialism with Chinese } \\
\text { characteristics) }\end{array}$ & $\begin{array}{c}\text { (American model of } \\
\text { capitalism) }\end{array}$ \\
\hline & $\begin{array}{c}\text { "Sageliness within and } \\
\text { kingliness without" }\end{array}$ & "Sageliness within" \\
\hline "Kingliness without" & $\begin{array}{c}\text { "Self cultivation", } \\
\text { "family harmony", } \\
\text { "country management" }\end{array}$ & "Self cultivation" \\
\hline "Country management" \\
and "world peace"
\end{tabular}




\begin{tabular}{|c|c|c|}
\hline & and "world peace" & \\
\hline & & \\
\hline State-oriented & Feelings to family and & Individual-oriented \\
& state & \\
\hline
\end{tabular}

In short, as summarized by Xi Jinping, the great social changes in contemporary China neither intend to carry on the master set of China's historical cultures, nor simply use the template assumed by the classical Marxist writer, nor become the reproduction of the socialist practice in other countries or the reprint of overseas modern development, and nor find an pre-existing textbook. Of course, socialism with Chinese characteristics is socialism instead of any other doctrine. Therefore, the basic principles of scientific socialism shall not be lost. If so, it is not socialism $^{20}$ anymore. The socialist path with Chinese characteristics is inherently different from "the third way", namely, democratic socialism. Economically, socialism with Chinese characteristics upholds the basic economic system whereby public ownership and distribution as per one's performance play a dominant role, and a better play is given to the government macro-control. Politically, socialism with Chinese characteristics upholds the leadership of the Communist Party of China, dictatorship of the proletariat and the socialist road. Ideologically and culturally, socialism with Chinese characteristics upholds the guide of Marxism. The most essential characteristic of socialism with Chinese

${ }^{20}$ Xi Jinping, The Governance Of China, Foreign Languages Press, 2014, 22. 
characteristics is the leadership of the Communist Party of China, while the greatest advantage of the the socialism with Chinese characteristics are also the leadership of the Communist Party of China ${ }^{21}$. The leadership of the Communist Party of China enables the "General Will" expressed by Rousseau to have the true representative, while the basic principle of democratic socialism is the improved bourgeois democracy, and cannot escape the disputes of class, party and interest group.

\section{Third, the Bright Prospect of Socialism with Chinese Characteristics, and the Chinese Cultural Renaissance}

For the Chinese attitudes towards the western culture, China's Chairman Mao Zedong once said, "All objects that are useful for us today, shall be absorbed. However, any foreign object, the same as our attitudes towards the food, must accept the mouth chewing and gastrointestinal movement, and be disintegrated into the essence and dross by the saliva, gastric juice and intestinal juice, and then be discharged with its dross and absorbed with its essence, which will benefit our health. However, it is not allowed to blindly and directly absorb without any selection." ${ }^{22}$ As the saying goes, "Chinese learning should be followed as the essence, while the western learning shall be followed as the practical application" 23 .

\footnotetext{
${ }^{21}$ Xi Jinping, The Governance Of China (Volume II), Foreign Languages Press, 2017, 43.

${ }^{22}$ Mao Zedong, Selected Works of Mao Zedong (Volume II), People's Publishing House, 1991, 707.

${ }^{23}$ Mao Zedong, Selected Works of Mao Zedong (Volume II), People's Publishing House, 1991, 707
} 
Therefore, both the socialism and capitalism are actually "utility" in China, while only Chinese modernization and the great rejuvenation of the Chinese nation are the "essence". Through learning the global advanced economic, political, cultural, social and ecological civilization construction experiences represented by the Soviet Union and USA, and in combination with China's own reality, China explores to realize the Chinese Dream of building China into a great modern socialist country that is prosperous, strong, democratic, culturally advanced, harmonious, and beautiful.

Chinese Wisdom Demonstrated by the Socialism with Chinese Characteristics

\begin{tabular}{|c|c|}
\hline \multicolumn{2}{|c|}{ The socialism with Chinese characteristics } \\
\hline \multirow{2}{*}{$\begin{array}{c}\text { Not only reject the old and rigid } \\
\text { closed-door policy }\end{array}$} & $\begin{array}{c}\text { But also reject any attempt to abandon } \\
\text { socialism and take an erroneous path }\end{array}$ \\
\hline $\begin{array}{c}\text { Not only adhere to the policy of } \\
\text { reform and opening up }\end{array}$ & $\begin{array}{c}\text { But also adhere to the Four Cardinal } \\
\text { experiences }\end{array}$ \\
\hline $\begin{array}{c}\text { Not only learn the western successful } \\
\text { expest }\end{array}$ & But also reject any simple copy of \\
& \\
\hline
\end{tabular}




\begin{tabular}{|c|c|}
\hline $\begin{array}{c}\text { Not only draw lessons from North } \\
\text { Korea and Cuba }\end{array}$ & $\begin{array}{c}\text { But also draw lessons from Soviet Union } \\
\text { and Eastern Europe }\end{array}$ \\
\hline $\begin{array}{c}\text { Not only emphasize China's national } \\
\text { conditions }\end{array}$ & But also respect the universal laws \\
\hline & \\
\hline Not only reject the "left" & But also reject the "right" \\
\hline
\end{tabular}

The Quotations from Goethe compiled by the Eckermann ${ }^{24}$ recorded the following comparison of Eastern and Western cultures made by this great thinker: The Chinese people are almost the same as us in thinking, action and emotion, which enables us to quickly feel that they are the same kind of person as us. However, everything in China is brighter, purer and more ethical than in Germany. In China, everything is understandable and approachable, without the strong lust and turbulent poetic mood. Meanwhile, another feature of them is the harmonious coexistence between people and nature. They keep the strict abstinence in every aspect, so that China can maintain its glory for thousands of years and may also continue forever. The "keeping the strict abstinence" highlighted by Goethe, actually distinguishes the difference between Eastern and Western cultures in a most accurate manner. For such both

24 J.K. Moorhedas (Ed.). Conversations of Goethe with Johann Peter Eckermann, Da Capo Press, 1998. 
sides as public ownership or private ownership, plan or market, freedom or discipline, democracy or centralism, single-party or multi-party, unification or diversification, the Chinese people will not be eager to judge which one is the perfect highest value. Instead, they will try to constrain both sides and realize the mutual harmony. Finally, socialism and capitalism are no longer endlessly fighting with each other. Instead, they are mutually promoted in the manner of "One Country, Two Systems".

Socialism with the Chinese characteristics is consistent with the Confucianism in spirit and mode of thinking. Therefore, it inherits the long lasting openness and inclusiveness tradition of Chinese cultures. Confucianism realizes the balance between the laissez-faire Taoism and Legalism of "severe punishment", while socialism with the Chinese characteristics realizes the balance between the laissez-faire capitalism and highly centralized socialism. Such balance is called "mean and harmony" by Confucianism and "unity of opposites" by socialism with Chinese characteristics. The "unity of opposites" is also the basic connotation of dialectical materialism, and the simplest summary of Marxist world outlook and methodology. Almost consistent with the basic connotation of "mean and harmony", it establishes the methodological precondition for integration of Marxism and Chinese cultures. Such spirit or mode of thinking of "mean and harmony" and "unity of opposites" establishes the unique openness and inclusiveness of the Confucianism and socialism with the Chinese characteristics as ideology. The religious conflict is the "absolutely irreconcilable" conflict. Therefore, a person who believes in Jesus Christ and also partially accepts Allah the Almighty is faithless. Besides, it is hard for religion to accept the atheistic Marxism. Due to the 
absolutely irreconcilable conflict between the Marxist "atheism" and religion. Therefore, it is hard for Marxism to become the political ideology in Germany, USA, UK and other countries where the religion is prevailing. Although Marxism was the national ideology in Soviet Union ever before, Russia with the long history of the Orthodox Eastern Church finally abandoned the Marxism. Although China has always had many religious beliefs, its official ideology Confucianism is not religion. Most dynasties in China's history adopts the Confucianism that adopts the worldly "self cultivation, family harmony, country management and world peace" as the objective, the Chinese folks develop the vast space for the joint development of many religions. Today's China also follows such pattern: the government believes in Marxist "atheism", while the masses have the freedom of religious belief. For the government where the Protestantism is prevailing, the Muslim, Buddhism and even Catholicism are the "paganism" with the wrong beliefs, and "atheism" is simply no different from "devil". However, for the "atheistic" government, the variable religious beliefs are the same and can reasonably exist on the condition that it shall not be involved in any political activity. Therefore, it is found that the Buddhist temple, Taoist temple, mosque, Catholic church and Christian church coexist in China, which is scarcely found in USA, Germany, UK, Russia and other countries.

The religious wars and persecution in history verify that the religious beliefs are absolutely irreconcilable, while the believers can only believe in the single God in heart and soul. Fundamentally, such religious complex of "believing in the single God" is not only the root cause of why the USA and Western European countries continuously peddle the 
democracy, freedom, human rights and other so called "universal values" worldwide, but also the root reason of why the conflicts between the Western European countries and the Muslim society occur. As the worldly ideology, the Confucianism and the socialism with the Chinese characteristics are reconcilable. Under the condition that the basic principle and position remain the same, the Confucian disciples may accept some Legalist ideas. Similarly, it is acceptable for the Socialist countries to learn the successful experiences from the capitalism. The Confucianism does not reject the Taoism and Buddhism. On the contrary, it always absorb the nutrition from these two contrary ideologies, which makes the Confucianism become more complete. Besides, the Legalism, Mohism, Logicianism, the Yin-Yang School and other Hundred Schools of Thought also greatly affect Confucianism. The British religious philosopher Karen Armstrong once accurately pointed out in his book The Great Transformation ${ }^{25}$ that all sorts of religion often domineer and mutually compete with each other in India and the Western countries, but people often say that a person may learn from the Confucianism in the day and learn from the Taoist at night in China. Even the Legalism is also not completely abandoned. The Chinese people need the Legalism during the kingdom's expansion period, so that the orthodox Confucian scholars may often criticize its ruler is "Outside Confucian; Inside Legalist". The broad consensus that every belief has its own scope of application is reached, while such ideological attitude at the axial age is what is urgently needed in our time. The socialism with the Chinese characteristics is just like this,

\footnotetext{
${ }^{25}$ Karen Armstrong, The Great Transformation, Anchor Books, 2007.
} 
which neither abandons the socialism, nor rejects the capitalism. Instead, the socialism with the Chinese characteristics not only adheres to the basic principle of the scientific socialism, but also absorbs the positive results of capitalism civilization. The socialism with the Chinese characteristics cannot be continuously perfected and developed, until it can continuously summarize the successful experiences and failure lessons of the socialism, and also continuously absorb the positive results of capitalism civilization, and criticize the disadvantages of the capitalism. In fact, not only the socialism of Soviet Union pattern and capitalism of American mode are always the major reference system of China, but also the experiences of Japan, Singapore, Taiwan, Hong Kong and other "Four Asian Tigers" are even the direct reference object of China. Meanwhile, China also pays close attention to the democratic socialism in Northwestern Europe. Without such intelligence and open-mindedness, the socialism with Chinese characteristics will not exist. Of course, China always think about and criticize all sorts of development pattern from China's specific national situations, while the socialism with Chinese characteristics will also not exist, without considering China's specific national situations. As the socialism with Chinese characteristics inherits the excellent Chinese cultural traditions of openness and inclusiveness, China neither criticize the socialism pattern of Cuba, nor simply mention the extinction of capitalism, and nor desires to treat its own pattern as the best pattern and promote it to the whole world, like America. Therefore, socialism with Chinese characteristics will definitely establish a good example to the world peace and harmony, and lays a solid foundation for spreading the 
Chinese people's beautiful dream of "all men are brothers within four seas".

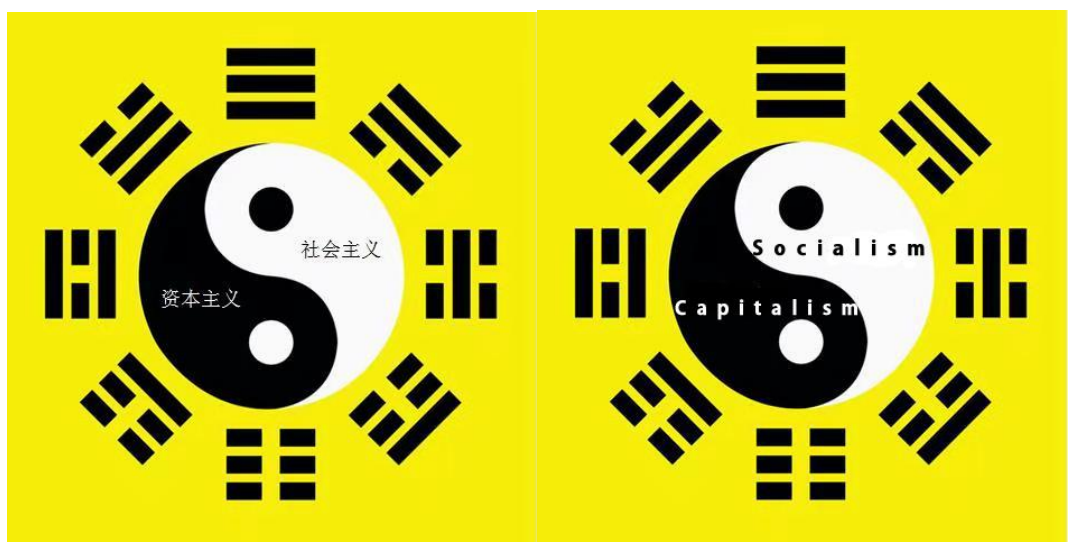

There is no future for the doctrine of "back to the ancients" that completely abandons both socialism and capitalism, but the human future is neither to abandon the "scientific socialism" with its own country's excellent traditions, nor to terminate the historical liberal democracy. The features of the socialism with the Chinese characteristics are the integration and combination of the two major modernized solutions, namely, the socialism and capitalism, and the Chinese excellent traditional cultures, while the intelligence of the modernized Chinese solutions and Chinese wisdom are the successful transcendence over the two major ideologies, namely, the socialism and capitalism. The modernized Chinese solutions and Chinese wisdom that can be contributed by China to our 
human beings are what the great philosopher Bertrand Arthur William Russell once said in his book The problem of China, "I believe that if the Chinese people can freely absorb their desired objects from our Western culture to offset the impacts of some bad factors in our Western civilization upon them, the Chinese people can absolutely have a sorts of organic development from their own cultural traditions, and can further bear the rich fruits that perfectly integrates the advantages of both the Western civilization and the Chinese civilization"26.

Data de registro: $30 / 07 / 2020$

Data de aceite: $21 / 10 / 2020$

26 Bertrand Russell, The Problem of China, Spokesman, 1993, 32. 